"the idioparasitic theory of cancer," a phrase which would, I think, remove all ambiguity ant would clear up the confusion which has been created in many minds by zalling the cancer cell a parasite simply.

Every one is unwilling to add new terms unnecessarily to the phraseology of science, already so cumbrous; but in the progress of linowledge and of scientitic ideas occasions must arise continually when new conceptions demant nerv terms for their expression, if confusion is to be avoided, and I venture to think that the case dealt with here is one which warrants the creation of a new term.I am, etc.,

London, S.W., Dec. 2nd.

E. A. Mischis.

\section{THE ORIGIN OF CANCER AND THE ORIGIN} OF LIFE.

Srr,-In his very interesting lectures on " Unicellula C'ancri" Sir Henry Butlin has shown in a striking manner. the parallelism that exists between the life and development of different varieties of cancer cells and that of many of the protozoa. He seeks to show, in fact, that " the carcinoma cell is an independent organism like many. a protozion," that it is " a complete animal organism in itself"; and he is now prepared to maintain this view "not only for carcinoma, but for every variety of malignant disease."

Looking to the generally admitted facts that, as Dr. Bashford says, "cancer arises de novo in each individual attacked," and that it occurs "by a transmutation of functional somatic into cancerous cells," as was originally pointed out by Farmer. Walker, and Moore in a paper. communicated to the Royal Society on December 7 th, 1905 ; together with the many analogies dwelt upon by Sir Henry Butlin, there seems very much to be said in favour of his view.

To some essential points in his statement, however, I must demur.

While all students of cancer are now practically agreed that cancer cells are derived from the tissue cells of the part in which they take their origin, this cannot correctly be spolien as a kind of process "which has never hitherto bcen imagined." It is exactly the kind of process known as "heterogenesis," many examples of which I have lescribed and illustrated in my Studies in Heterogenesis (1903), and it is a process which has been defincl as "the production from the substance of organisms or their germs of alien forms of life." ${ }^{\prime}$ It is tiue that transmutation here iloes not lead to the production from the altered tissue colls of what would be generally almitted to be inclependent living organisms, and certainly the process cannot possibly be cited as an illustration of "the origin of life." Life was alreadly existent in the tissue cell, its mode of life lias only been changed, a process allied to heterogenesis has occurred. I cannot, therefore, agrec with Sir Henry Butlin when he goes on to say:

The host in which it dwells has fashioned it out of its own tissues, and, to borrow the figurative language of Scripture,
the Creator has breathed into it the breath of life .. . After ages of past and present civilization, during which searchers and philosophers have sought to explain the origin and nature of philosophers have sought to explain the
life, we have come no further than this.

The true origin of cancer, as I maintain, is related to leterogenesis, and not, as he thinks, to the still more mys. terious problem to which he refers. Nor can it fairly be said that in regard to the solution of this problem we have come no further than the establishment of this particular instance of heterogenesis.

Probably Sir Henry Butlin has never studied my little book, entitled, The Origin of Life (1911), where experiments are described in which multitudes of independent living organisms have been taken from tubes, previously hermetically scaled, containing certain saline fluids which had some months before been lieated for periods varying from five to twenty minutes to temperatures ranging from $125^{\circ}$ to $145^{\circ} \mathrm{C}$., while most of the organisms that had been produced within the tubes were such (torulae and micrococci) as are known to be lilled by exposure in fluids to $60^{\circ}$ to $70^{\circ} \mathrm{C}$. for a few minutes. Such experiments surely take us much further towards the solution of " the great cnigma" than does any mere proof of the heterogenetic

${ }^{1}$ An illustrated description of one of the most notable cxamples observed by me may be seen in the proccitings of the Roya? Society,
vol. B. 76 (1905), 1p. 385-392. origin of cancer. cells, however much they may be shown to be related to many of the protozoa.-I am, etc.

London, S.W., Dec. 2nd. H. Charlton Bastiax.

\section{THE VARIETIES AND TREATMENT OF} ASTHMA.

Sir,-Though at first sight the series of phenomena cited by Dr. Francis Hare may seem to lend strong support to the liypothesis of vasomotor engorgement of the brouchial mucosa, which he maintains is the essential cause of the dyspnoea of asthma, there are a few clinical facts which $I$ suggest are incompatible with his thesis.

For instance, we know that in acute bronchitis tho bronchial mucosa is intensely hyperaemic and is swollen, yet asthma does not occur in the great niajority of such cases. It is true that in a small percentage of cases of acute bronchitis the inflammatory irritation of the mucosa, definite asthma does appear, particularly in the early stiges, only to subside as the secondary eugorgement develops, though in a still smaller percentage the asthma persists. Why, then, should we suppose that vascular. engorgement or vasomotor dilatation is the ess ?ntial cause of bronchial asthma? And eren if Dr. Hare had succeeded in proving that hyperacmia of the bronchial mucosa is coustantly present at the commencement of an asthmatic paroxysm, and subsided with the relief of the dyspnoea, one cannot get away from the fact that, apart from a rhythmical dilatation and contraction of the bronchi, such swelling of the bronchial mucosa must cause as much obstruction to the entrance as to the exit of air througli the narrowed lumina.

How does Dr. Hare propose to explain the effects on an asthmatic paroxysm of morphine and of chloroform inhalations? Does morphine cause rapid vascular constriction in the swollen bronchial mucosa? If so, what a useful remedy morphine must be in, say, the capillary bronchitis of young children! I do not think chlorofor'm inhalations can be beld to constrict the bronchial vessels, but very few attacks of asthma fail to yicld to chloroform.

All the points advanced by Dr. Harc in support of his view seem to me comparable to the argument that because removal of a small nasal spur will sometimes inhibit asthmatic attacks for a time the spur must have been the essential cause of the trouble, whereas the real explanation is that the irritation of the fifth nerve on the septum, whether by operative interference or by galvanocauterization, influences the bulbar respiratory centres.

I hope that Dr. Hare will do me the favour of explaining the difficulties $I$ suggest in acer $t i \cdot g$ his views, and perhaps offer some arguments wh o h militate against my suggestion that the expiratory dyspuvea of asthma is due to bronchiolar contraction during expiration with relative dilatation during inspiration.

I note that Dr. Hare states that vascular engorgement has often been seen, whether by the naked eye or the laryngoscope, in all those parts of the respiratory tract which are exposed to view. Now, I happen to have hart fairly good experience in laryngoscopy, but I am bound to admit that laryngoscopic examination during an asthmatic paroxysm is by no means an easy procedure, and thougl I have succeeded in obtaining a view of the larynx in a ferv cases, my experience is opposed to those to whom Dr. Haro refers. But $I$ have only seen tbe vocal cords and supraglottic portions of the laryns at all well; the view of the trachea has been too fleeting for me to contradict those who have been more skilful. May I ask who are Dr. Hare's authorities?

If Dr. Hare will offer us ad cuate explanation of tho facts I have alluded to, he will, $\mathrm{cr}$ ise our indebtednes. to him for so much that is valuabie in the clinical management of asthma, about which we have all a great deal to learn before we are on safe and altogether satisfactory ground.-I am, etc.,

Clifton, Lristol, Dec. 3rd.

P. Watson-Williams, M.D.Lond.

PAYING HOSPITALS FOR PRIVATE PATIENTS.

SIR,-The interesting letter on this subject by $\mathrm{M}_{1}$. Lawrie McGavin (British Medical Journal, December 2nd, p. 1506) prompts me to bring before your reader's a brief ontline of a scheme for the establishment of a large new nursing home for patients of limited means which is 